\title{
PENGARUH CARA SKARIFIKASI DALAM PEMATAHAN DORMANSI PADA VIABILITAS BENIH SAGA MANIS (Abrus precatorius [L.])
}

\author{
Yayuk Nurmiaty, Ermawati \& Vita Wulan Purnamasari \\ Jurusan Agroteknologi, Fakultas Pertanian Universitas Lampung \\ Jl. Prof. Soemantri Brodjonegoro, No. 1, Bandar Lampung 35145 \\ E-mail: vitawulanpurnamasari060113@ gmail.com
}

\begin{abstract}
ABSTRAK
Penelitian ini bertujuan untuk mengetahui apakah cara skarifikasi dapat meningkatkan viabilitas benih saga manis. Penelitian ini dilaksanakan di Laboratorium Teknologi Benih dan Pemuliaan Tanaman Universitas Lampung pada Maret 2012. Rancangan percobaan disusun dalam rancangan kelompok teracak sempurna (RKTS), dengan waktu panen sebagai dasar pengelompokan. Setiap perlakuan diulang sebanyak empat kali. Setiap ulangan menggunakan 25 butir benih saga manis. Rancangan perlakuan adalah tunggal tidak terstruktur terdiri dari kontrol, tiga perlakuan mekanik yaitu dengan menggunakan pelukaan dengan gunting kuku di kotiledon $\left(\mathrm{B}_{1}\right)$, pengamplasan di kotiledon $\left(\mathrm{B}_{2}\right)$, dan pengamplasan di hilum $\left(\mathrm{B}_{3}\right)$. Data diuji Bartlett untuk mengetahui homogenitas ragam perlakuan dan pengaruh-pengaruh utama yang bersifat aditif (menambah) diuji dengan uji Tukey. Jika data homogen dan bersifat aditif maka dilanjutkan dengan analisis ragam. Pengujian nilai tengah dilakukan dengan uji BNJ pada taraf $\alpha_{0.05}$. Skarifikasi mekanik dengan pelukaan gunting kuku menunjukkan viabilitas benih saga manis tertinggi; daya berkecambah sebesar $100 \%$, kecepatan perkecambahan sebesar $23,22 \%$ /hari, panjang akar kecambah normal sebesar 18,18 cm, bobot kering kecambah sebesar $0,79 \mathrm{~g}$, dan bobot kering hipokotil sebesar 0,480 $\mathrm{g}$.
\end{abstract}

Kata kunci: dormansi benih, viabilitas, saga manis, skarifikasi

\section{PENDAHULUAN}

Industri obat tradisional Indonesia berkembang pesat baik sebelum maupun selama krisis multidimensional melanda Indonesia. Perkembangan industri obat yang pesat tercermin dari jumlah perusahaan pendukungnya. Pada tahun 1981, jumlah perusahaan obat baru mencapai 165 buah, tetapi pada tahun 1991 dan tahun 2000, jumlah tersebut meningkat masingmasing menjadi 427 dan 985 perusahaan. Pasokan bahan baku industri obat tradisional masih mengandalkan hasil pemanenan dari hutan atau habitat alami, sekitar $80 \%$ dipasok dari hasil budi daya secara tradisional.

Perkembangan industri obat tradisional dan pasokan bahan baku yang masih mengandalkan pada alam telah menyebabkan terjadi penurunan genetik sehingga 54 jenis tanaman obat menjadi langka. Jumlah spesies tumbuhan obat yang telah berhasil diindentifikasi sekitar 1.845 spesies, dan 95 spesies diantaranya merupakan tumbuhan obat liar yang saat ini dieksploitasi dalam jumlah besar (Proyek Pengelolaan dan Pemulihan Kerusakan Lingkungan dan Fakultas Kehutanan IPB, 2001). Industri obat tradisional di Indonesia berkembang cukup pesat. Perkembangan industri obat yang pesat tercermin dari jumlah perusahaan obat sebagai pendukungnya. Permasalahan pengembangan industri obat tradisional adalah sebagian besar bahan baku (sekitar 80\%) masih mengandalkan hasil pemanenan dari hutan atau habitat alami, sisanya (20\%) berasal dari hasil budidaya secara tradisional (Hasanah dan Rusmin, 2006).

Salah satu jenis bahan tanaman yang diperlukan sebagai bahan baku obat tradisional adalah saga manis (Abrus precatorius [L.]) dari famili Leguminoceae. Jenis ini hidup di kawasan Asia yang beriklim tropika. Di Jawa, prospek pembudidayaan tanaman saga ini sangat cerah, karena tanaman ini dapat tumbuh liar di daerah basah yang tingginya berkisar 50-1.650 meter dari permukaan laut dan di tempat-tempat yang mempunyai drainase yang baik dan cukup air air (Nurawan, Hadad, dan Sitepu, 1993).

Peluang pembudidayaan tanaman saga manis ini sangat besar dan cukup menarik untuk diusahakan secara komesial, karena hampir seluruh tanaman saga manis dapat dimanfaatkan. Bagian tanaman yang dikembangkan dalam industri obat tradisional yaitu bagian biji, daun, batang, dan akar. Bagian biji dapat digunakan sebagai insektisida nabati karena mengandung tanin dan toksalbumin yang daya kerjanya menyerupai racun ular, bila biji saga manis diekstrak dengan air atau aseton (Kardinan, 1999). Bagian daun juga dapat dimanfaatkan sebagai obat diare dan wasir (Nurawan, 
Hadad, dan Sitepu, 1993). Daun saga manis juga berkhasiat untuk wasir, mengobati sariawan, antiparasit, antiradang, meredakan batuk dan panas dalam, dan melancarkan peredaran darah. Dari sejumlah penelitian yang dilakukan, saga mengandung abruslactone A, methyl abrusgenate, abrusgenic acid, vitamin $\mathrm{C}$, dan kadar glisirisin.

Budidaya tanaman saga manis memilliki kendala yaitu mempunyai sifat dormansi yang disebabkan oleh kulit yang kedap terhadap air (Purwanto dan Roemantyo, 1993). Usaha untuk mematahkan dormansi kulit keras (hard seeds) dapat dilakukan dengan cara skarifikasi. Metode skarifikasi mencakup cara pelukaan dengan gunting kuku di kotiledon pada biji saga manis, pengamplasan di kotiledon, dan pengamplasan hilum.

Pengguntingan cadangan makanan, pengamplasan cadangan makanan, atau pengamplasan hilum paling sedikit harus menembus kutikula (lapisan lilin) dan setengah dari lapisan malpigi. Skarifikasi secara manual dapat efektif pada seluruh permukaan kulit benih, tetapi daerah micropylar yang terdapat radikel harus dihindari (Cremer, 1990 yang dikutip Schmidt, 2000). Tujuan penelitian ini untuk mengetahui apakah cara skarifikasi dapat meningkatkan viabilitas benih saga manis.

\section{BAHAN DAN METODE}

Penelitian ini dilaksanakan di Laboratorium Teknologi Benih dan PemuliaanTanaman Universitas Lampung pada bulan Maret 2012. Bahan-bahan yang digunakan dalam percobaan ini adalah benih saga manis dipanen pada tanggal yaitu panen pertama pada 26 Juni 2011 untuk kelompok satu, panen kedua pada 5 Juli 2011 untuk kelompok dua, dan panen ketiga pada 5 Juli 2011 untuk kelompok tiga. Serta aquades, air panas, kertas koran CD, plastik lembaran, karet, dan label. Alat yang digunakan adalah alat pengecambah benih tipe M-12, gunting kuku, amplas, gelas ukur, pipet, nampan, oven, alat timbang elektrik, dan alat tulis.

Rancangan percobaan disusun dalam rancangan kelompok teracak sempurna (RKTS), dengan waktu panen sebagai dasar pengelompokan. Setiap perlakuan diulang sebanyak empat kali. Setiap ulangan menggunakan 25 butir benih saga manis (Gambar 1A). Rancangan perlakuan adalah tunggal tidak terstruktur terdiri dari kontrol (Gambar 1B), tiga perlakuan mekanik yaitu dengan menggunakan pelukaan dengan gunting kuku di kotiledon $\left(\mathrm{B}_{1}\right)$ (Gambar 1C), pengamplasan di kotiledon $\left(\mathrm{B}_{2}\right)$ (Gambar 1D), dan pengamplasan di hilum $\left(\mathrm{B}_{3}\right)($ Gambar 1E). Penelitian ini dilakukan dalam Rancangan Kelompok Teracak Sempurna (RKTS) dengan empat ulangan. Data diuji Bartlett untuk mengetahui homogenitas ragam perlakuan dan pengaruhpengaruh utama yang bersifat aditif (menambah) diuji dengan uji Tukey. Jika data homogen dan bersifat aditif maka dilanjutkan dengan analisis ragam. Pengujian nilai tengah dilakukan dengan uji BNJ pada taraf $5 \%$.

\section{HASIL DAN PEMBAHASAN}

Hasil penelitian menunjukkan bahwa pematahan dormansi dengan cara skarifikasi dapat menghasilkan daya berkecambah yang berbeda. Daya berkecambah

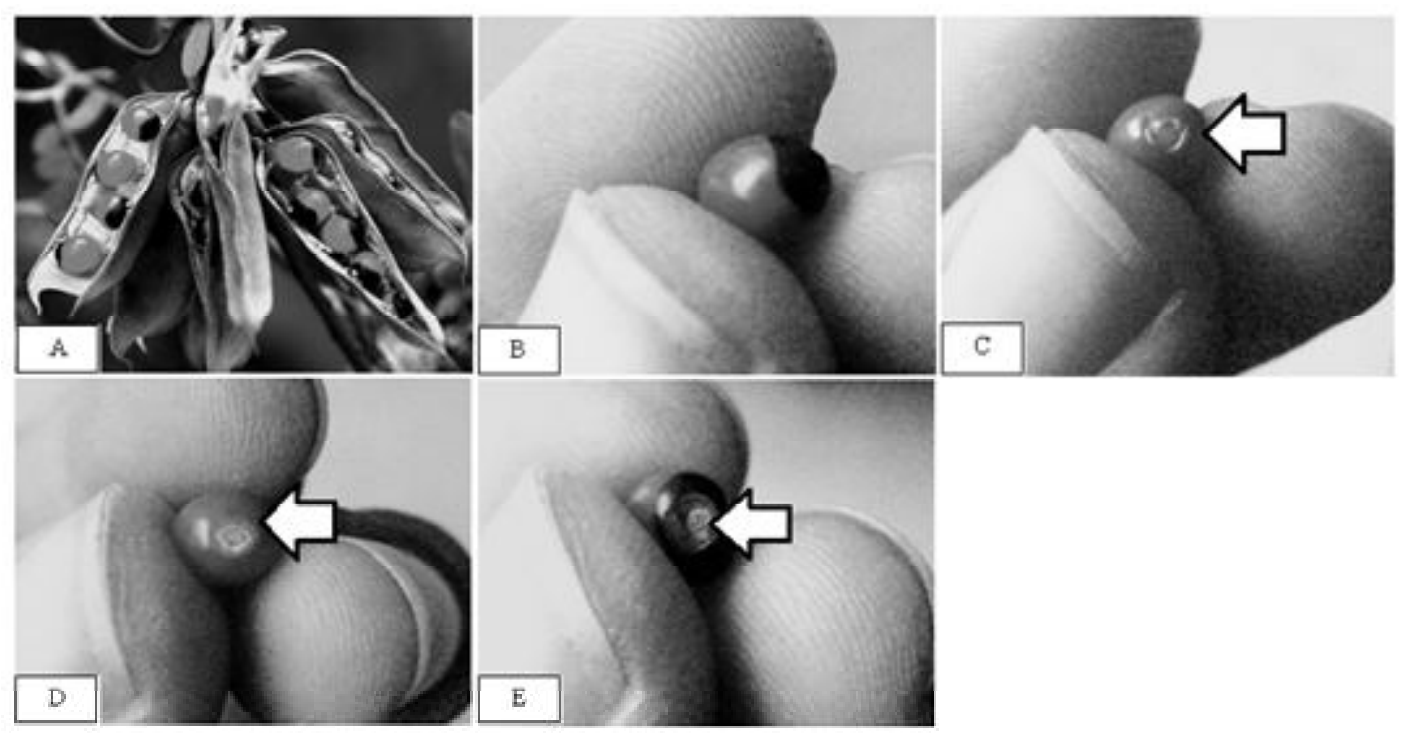

Gambar 1. A = Biji saga manis, $\mathrm{B}=$ Benih saga manis tanpa diberi perlakuan (kontrol), $\mathrm{C}=$ Pelukaan dengan gunting kuku di kotiledon pada benih saga manis, $\mathrm{D}=$ Pengamplasan di kotiledon pada benih saga manis, dan $\mathrm{E}=$ Pengamplasan di hilum pada benih saga manis. 
yang dihasilkan tertinggi dari skarifikasi mekanis yaitu pelukaan dengan gunting kuku di kotiledon, diikuti pengamplasan di kotiledon, pengamplasan di hilum, dan terendah kontrol (Tabel 1).

Hasil penelitian menunjukkan bahwa pematahan dormansi dengan cara skarifikasi dapat menghasilkan kecepatan perkecambahan yang berbeda. Kecepatan perkecambahan yang dihasilkan tertinggi dari skarifikasi mekanis yaitu pelukaan dengan gunting kuku di kotiledon, diikuti pengamplasan di kotiledon, pengamplasan di hilum, dan terendah kontrol (Tabel 1).

Hasil penelitian menunjukkan bahwa pematahan dormansi dengan cara skarifikasi dapat menghasilkan panjang kecambah normal yang berbeda. Panjang kecambah normal yang dihasilkan tertinggi dari skarifikasi mekanis yaitu pelukaan dengan gunting kuku dan pengamplasan di kotiledon, diikuti pengamplasan di hilum, dan terendah kontrol (Tabel 1).

Hasil penelitian menunjukkan bahwa pematahan dormansi dengan cara skarifikasi dapat menghasilkan bobot kering kecambah normal yang berbeda. Bobot kering kecambah normal yang tertinggi dihasilkan dari skarifikasi mekanis yaitu pelukaan dengan gunting kuku di kotiledon dan terendah kontrol. Bobot kering kecambah normal dari pelukaan dengan gunting kuku di kotiledon lebih tinggi dari pengamplasan di hilum (Tabel 1).

Hasil penelitian menunjukkan bahwa pematahan dormansi dengan cara skarifikasi dapat menghasilkan bobot kering hipokotil yang berbeda. Bobot kering hipokotil yang tertinggi dihasilkan dari skarifikasi mekanis yaitu perlakuan gunting kuku dan terendah kontrol. Bobot kering hipokotil dari pelukaan gunting kuku di kotiledon, diikuti pengamplasan di kotiledon, pengamplasan di hilum, dan terendah kontrol (Tabel 1). Hasil penelitian menunjukkan bahwa skarifikasi dapat mematahkan dormansi benih saga manis yang ditunjukkan oleh semua peubah yang diukur. Cara skarifkasi mekanik yang lebih efektif dalam pematahan dormansi benih saga adalah pelukaan dengan gunting kuku di kotiledon. Hal ini ditunjukkan pada peubah daya berkecambah, kecepatan perkecambahan, panjang kecambah normal, bobot kering kecambah normal, dan bobot kering hipokotil. Dari hasil semua variabel tersebut, pelukaan dengan gunting kuku di kotiledon menunjukkan hasil yang paling tinggi. Hal ini diduga karena luasan pelukaan gunting kuku lebih besar daripada pengamplasan di hilum, sehingga air dan gas lebih mudah masuk ke dalam benih.

Skarifikasi mekanik dengan pelukaan gunting kuku memungkinkan kulit benih terluka sehingga dapat dilewati air dan terjadi proses imbibisi. Skarifikasi mampu memberikan kondisi tidak kedap pada kulit benih (yang mulanya kedap) sehingga benih dapat menyerap air. Air masuk ke dalam benih menyebabkan aktivasi enzim, perombakan cadangan makan, transpor molekul, peningkatan respirasi dan asimilasi, insiasi pembelahan dan pembesaran sel, dan pemanjangan sel radikel diikuti munculnya radikel dari kulit benih dapat terjadi. Air tersebut tidak saja mempercepat munculnya radikel, juga meningkatkan pertumbuhan bagian embrio yang lainnya sehingga kecambah normal yang terbentuk juga tinggi. Hal ini ditunjukkan oleh hasil daya berkecambah tertinggi dari pelukaan gunting kuku.

Daya berkecambah yang tinggi merupakan hasil proses metabolisme perkecambahan benih yang berlangsung cepat dan cukup tersedia cadangan makanan dalam benih. Cadangan makanan yang cukup sangat dibutuhkan sebagai substrat respirasi untuk menghasilkan energi dalam meningkatkan metabolisme perkecambahan. Hal ini ditunjukkan dari hasil penelitian bahwa kecepatan berkecambah, panjang kecambah

Tabel 1. Pengaruh skarifikasi terhadap perlakuan benih saga manis.

\begin{tabular}{lllllllllll}
\hline \multicolumn{1}{c}{ Perlakuan } & $\begin{array}{c}\text { Daya } \\
\text { berkecambah } \\
(\%)\end{array}$ & $\begin{array}{c}\text { Kecepatan } \\
\text { perkecambahan } \\
(\% / \text { hari })\end{array}$ & $\begin{array}{c}\text { Panjang akar } \\
\text { kecambah } \\
\text { normal }(\mathrm{cm})\end{array}$ & $\begin{array}{c}\text { Bobot kering } \\
\text { kecambah } \\
\text { normal }(\mathrm{g})\end{array}$ & $\begin{array}{c}\text { Bobot kering } \\
\text { hipokotil } \\
(\mathrm{g})\end{array}$ \\
\hline $\begin{array}{l}\text { Kontrol } \\
\begin{array}{l}\text { Pelukaan dengan } \\
\text { gunting kuku di }\end{array}\end{array}$ & 0,00 & $\mathrm{~d}$ & 0,00 & $\mathrm{~d}$ & 0,00 & $\mathrm{c}$ & 0,00 & $\mathrm{c}$ & 0,000 & $\mathrm{~d}$ \\
$\begin{array}{l}\text { kotiledon } \\
\begin{array}{l}\text { Pengamplas an di } \\
\text { kotiledon }\end{array}\end{array}$ & $100,00 \mathrm{a}$ & 23,22 & $\mathrm{a}$ & 18,18 & $\mathrm{a}$ & 0,79 & $\mathrm{a}$ & 0,480 & $\mathrm{a}$ \\
$\begin{array}{l}\text { Pengamplasan di hilum } \\
\text { BNJ 0,05 }\end{array}$ & 62,00 & $\mathrm{~b}$ & 21,19 & $\mathrm{~b}$ & 16,37 & $\mathrm{~b}$ & 0,69 & $\mathrm{ab}$ & 0,440 & $\mathrm{~b}$ \\
\hline Ken & $\mathrm{c}$ & 15,47 & $\mathrm{c}$ & 11,78 & $\mathrm{c}$ & 0,58 & $\mathrm{~b}$ & 0,380 & $\mathrm{c}$ \\
\hline
\end{tabular}

Keterangan: Nilai tengah yang diikuti oleh huruf yang sama pada kolom yang sama tidak berbeda nyata berdasarkan uji BNJ pada $\alpha_{0,05}$. 
normal, bobot kering kecambah normal, dan bobot kering hipokotil juga tertinggi, diperoleh dari pelukaan gunting kuku.

Menurut Juanda (2013), laju imbibisi yang baik menyebabkan kebutuhan air untuk benih terpenuhi sehingga proses metabolisme benih dapat berjalan dengan baik. Proses metabolisme benih yang baik menyebabkan terjadinya perkecambahan yang baik. Skarifikasi menyebabkan terjadinya peningkatan permeabilitas kulit benih sehingga laju imbibisi benih tinggi. Laju imbibisi yang tinggi diikuti dengan penguraian cadangan makanan yang tinggi, hal ini ditunjukkan oleh variabel perkecambahan yang diamati seperti daya berkecambah, kecepatan berkecambah, dan keserempakan berkecambah. Hasil penelitian ini mendukung penelitian Juanda (2013).

Skarifikasi secara manual dapat efektif pada seluruh permukaan kulit benih, tetapi di daerah micropylar yang terdapat radikel harus dihindari. Kerusakan pada daerah ini dapat merusak benih sedangkan kerusakan kecil pada kotiledon tidak mempengaruhi perkecambahan (Schmidt, 2000). Pada hakekatnya semua benih dibuat permeabel dengan risiko kerusakan yang kecil, asal daerah radikel tidak rusak. Dari semua variabel yang diamati, perlakuan kontrol menunjukkan hasil yang paling rendah. Benih saga yang tanpa diberi perlakuan, air sulit masuk ke dalam benih sehingga imbibisi sebagai awal perkecambahan benih tidak dapat terjadi.

Untuk mempercepat perkecambahan benih saga dalam dalam jumlah besar dan dalam waktu yang cepat dapat dilakukan perlakuan benih dengan cara skarifikasi fisik dan kimia selain perlakuan mekanik tersebut. Perlakuan benih secara fisik seperti perendaman benih dalam air menyebabkan terjadinya pelunakan kulit benih yang akhirnya akan mengisi ruang-ruang antarmolekul dan antarmisel benih. Air yang masuk akan meningkatkan tekanan dalam benih yang menyebabkan terjadinya keretakan pada kulit benih dan mengatur masuknya air ke dalam benih selama proses perkecambahan. Menurut Schmidt (2000), pengaruh lama perendaman pada benih keras sangat bervariasi. Perendaman yang berlangsung lama dalam air mengalir selama satu sampai beberapa hari juga berfungsi untuk mencuci zat-zat yang menghambat dan melunakkan kulit benih.

Perlakuan benih secara kimia seperti perendaman dalam asam sulfat merupakan alternatif yang juga berfungsi untuk mencuci zat-zat yang menghambat dan melunakkan kulit benih. Lama perlakuan tergantung dari ketebalan kulit benih, suhu, konsentrasi asam, dan volume asam. Menurut Salisbury dan Ross (1995), larutan asam kuat seperti asam sulfat pekat ditujukan untuk melarutkan bahan lilin yang terdapat pada kulit benih yang menghalangi masuknya air.

\section{KESIMPULAN}

Kesimpulan dari penelitian ini adalah skarifikasi mekanik dengan pelukaan gunting kuku menunjukkan viabilitas benih saga manis tertinggi; daya berkecambah sebesar $100 \%$, kecepatan perkecambahan sebesar 23,22 $\%$ hari $^{-1}$, panjang akar kecambah normal sebesar 18,18 $\mathrm{cm}$, bobot kering kecambah sebesar $0,79 \mathrm{~g}$, dan bobot kering hipokotil sebesar 0,480 g.

\section{UCAPAN TERIMA KASIH}

Ucapan terima kasih disampaikan kepada Ibu Dr. Ir. Nyimas Sa'diyah, M.P., selaku Penguji yang telah memberikan masukan dalam penyempurnaan tulisan ini.

\section{DAFTAR PUSTAKA}

Chairunisa, N. 2005. Pengaruh cara skarifikasi dalam pematahan dormansi pada perkecambahan benih saga manis (Abrus precatorius [L.]). Skripsi. Universitas Lampung. Bandar Lampung. 8-9 hlm.

Hasanah, M. dan D. Rusmin. 2006. Teknologi pengelolaan benih beberapa tanaman obat di Indonesia. Balai penelitian tanaman obat dan aromatik. Jurnal Litbang Pertanian. Vol 25(2): 69-70.

Juanda, 2013. Pengaruh skarifikasi pada pola imbibisi dan perkecambahan benih saga manis (Abruss precatorius [L.]). Jurnal Agrotek Tropika. Vol 1: 45-49.

Kardinan, A. 1999. Pestisida Nabati: Ramuan dan Aplikasi. Penebar Swadaya. Jakarta. $80 \mathrm{hlm}$.

Nurawan, A., E.A. Hadad, dan D. Sitepu. 1993. Penanggulangan penyakit penting pada tanaman tempuyung dan saga manis. Jurnal warta tumbuhan obat Indonesia. Pusat Penelitian dan Pengembangan Farmasi. 2(2): 21-22.

Proyek Pengelolaan dan Pemulihan Kerusakan Lingkungan dan Fakultas Kehutanan IPB. 2001. Rancangan strategi konservasi tumbuhan obat Indonesia. Executive Summary. Kerja Sama Proyek Pengelolaan dan Pemulihan Kerusakan Lingkungan dengan Fakultas Kehutanan Institut Pertanian Bogor. $48 \mathrm{hlm}$. 
Purwantoro, R.S. dan Roemantyo. 1993. Konservasi tempuyung dan saga manis suatu studi Kebun Raya Bogor. Jurnal warta tumbuhan obat Indonesia. Pusat Penelitian dan Pengembangan Farmasi. Vol. 2(2): 18-20.

Salisbury, F.B. dan C.W. Ross. 1995. Fisiologi Tumbuhan. Jilid 2. Institut Teknologi Bandung. Bandung. Hlm. 133-140.
Schmidt, L. 2000. Pedoman penanganan benih tanaman hutan tropis dan subtropis. Diterjemahkan oleh Direktoral Jenderal Rehabilitasi Lahan dan Perhutanan Sosial Departemen Kehutanan. PT Gramedia. Jakarta. $530 \mathrm{hlm}$.

Yuniarti, N. 2002. Penentuan cara perlakuan pendahuluan benih saga pohon. Jurnal Manajemen Hutan Tropika. 8(2): 97-101. 